\title{
Anadolu Süslemelerindeki Geometri
}

\author{
Jale İPEK $^{1} \quad$ Pelin ÖZMÜŞ ${ }^{2}$
}

Geliş Tarihi: 27.08.2013 Kabul Tarihi: 05.12.2014

\section{Öz}

Bilim ve teknolojideki gelişmeler her meslek alanında olduğu gibi eğitim alanına da yeni bilgiler ve teknik araçlar getirmektedir. Teknolojinin getirdiği bu yenilik ve değişikliklerin öğrenme ortamlarıyla entegrasyonunun etkili bir şekilde sağlanması gerekir. Genelde matematik, özelde de geometri ve sanat ilişkisi son zamanlarda pek çok tartışmaya konu olmaktadır. Bu çalışmada, 2011-2012 öğretim yılında Ege Üniversitesi Eğitim Fakültesi'nde öğrenim gören, "Özel Öğretim Yöntemleri” dersini alan toplam 125 Matematik Formasyon ve Bilişim Teknolojileri öğretmen adayının bitirme projesi incelenmiştir. Öğretmen adayları bu ders kapsamında Geometer's Sketchpad programını da öğrenmişlerdir. Öğretmen adayları bitirme projelerinin temalarını seçme konusunda özgür bırakılmışlardır. Öğretmen adayları seçtikleri süslemeleri Geometer's Sketchpad programı yardımıyla oluşturmuşlardır. Toplam 42 öğretmen adayı bitirme projesi teması olarak "Anadolu Süslemeleri” ni seçmiştir. Bu çalışmanın amacı, "Anadolu Süslemeleri” temasını seçen öğretmen adayları arasından farklı süslemeleri kullananların bu süslemelere ulaşırken izledikleri yollar ve kullandıkları geometrideki bazı önemli kavramları göstermektir. Bu kavramlar; "Anadolu Süslemeleri”nde de kullanılan düzgün çokgenlerin oluşumu, bir çember içine çizilen ve etrafında dolanan şekillerin oluşturulması, açıların ve doğruların verilen bir sayı kadar eşit parçaya bölünmesi, şekillerin yansıma, öteleme ve dönmeleri, simetri grupları, süslemelerin renklendirilmesi ve daha pek çoğudur. Ayrıca öğretmen adaylarından bitirme projelerinin yanında dersin işlenişi, Geometer's Sketchpad programı ve kendi yaptıkları ödevleri ile ilgili görüşlerini yazmaları da istenmiştir. $\mathrm{Bu}$ görüşler incelendiğinde tüm öğretmen adaylarının dersin uygulamalı olarak işlenmesinin yararlı, Geometer's Sketchpad'in geometri öğretiminde oldukça faydalı olacağı ve yaratıcılıklarına olumlu etki sağladığını ifade ettikleri gözlemlenmiştir.

Anahtar Kelimeler: Matematik ve sanat, geometri, Anadolu Süslemeleri, Geometer's Sketchpad.

\footnotetext{
${ }^{1}$ Doç.Dr., Ege Üniversitesi, Eğitim Fakültesi, B.Ö.T.E., Öğretim Elemanı jale.ipek@ege.edu.tr ${ }^{2}$ Matematik Öğretmeni Ege Üniversitesi, Eğitim Fakültesi, B.Ö.T.E., Yüksek Lisans Öğrencisi pelinozmus@hotmail.com
} 


\title{
Geometry in Anatolian Ornaments
}

Submited by 27.08.2013 Accepted by 05.12.2014

\begin{abstract}
The development in science and technology brings new knowledge and technical tools into every job field as well as in to the education field. This new improvement and change should be well integrated with the education field. Usually mathematics, the relationship between geometry and art in particular lately has been the topic for many discussions. In this work, the final project of 125 Mathematics Formation and Information Technologies pre-service teachers that take "Special Education Method" have been examined. Pre-service teachers also learnt how to use Geometer's Sketchpad within this lesson. Pre-service teachers were free to choose the theme of their final project. Pre-service teachers prepared the patterns of their own choice by using Geometer's Sketchpad. In total of 42 pre-service teachers have chosen "Anatolian Ornaments" for the theme of their final project.

The purpose of this study is showing the different ways of getting to these patterns and the some important concept in geometry of the pre-service teachers that have chosen different patterns among the ones that have chosen "Anatolian Ornaments" theme. These concepts are the ones that are also use in "Anatolian Ornaments", such as the creation of the regular polygons, motives that are drawn into a circle and orbiting around it, dividing the angles and lines in to the parts equal to the given number, the reflection, rotations and symmetry groups of the motives, coloring the motives and many more. Also besides the final project, the preservice teacher were asked to write their opinion about the way the lesson is being taught, Geometer's Sketchpad program and the homework that they worked on. When we went through the opinions, we saw that the most of the pre-service teachers think that the practical teaching is beneficial and Geometer's Sketchpad is very useful for teaching geometry.
\end{abstract}

Key words: Mathematics and Art, geometry, Anatolia Ornaments, Geometer’s Sketchpad 


\section{Giriş}

Bilim ve teknolojideki gelişmeler her meslek alanında olduğu gibi eğitim alanına da yeni bilgiler ve teknik araçlar getirmektedir. Teknolojinin getirdiği bu yenilik ve değişikliklerin öğrenme ortamlarıyla entegrasyonunun etkili bir şekilde sağlanması gerekir. Genelde matematik, özelde de geometri ve sanat ilişkisi son zamanlarda pek çok tartışmaya konu olmaktadır.

Altun (2005), "Matematik bir düşünme yoludur, bir sanattır, yapıların ve ilişkilerin bir çalışmasıdır.” şeklinde matematiği tanımlamıştır. İnformal geometri, kişinin çevresindeki objeler hakkındaki uzamsal düşüncesinin gelişmesini amaçlar (NCTM, 1989, s.49).

Öğrenci, bir matematikçi gibi verilen problemlere kendi çözüm yollarını oluşturarak, bu çözüm yolları üzerine sınıf içi tartışmalar sonucunda bir genellemeye varabilir. Öğrenciler problemlere çözüm oluştururken, verilen durumları analiz eder, bir desen arar ve bu desenleri düzenleyerek bir genellemeye ulaşmaya çalışır. Matematik öğrenimi de bu süreç içinde gerçekleşir. Bu tarz bir matematik öğretiminde konu öğretiminin yanında, daha ileri düzey becerilerin geliştirilmesi amaçlanmaktadır. Bu beceriler veriye dayalı akıl yürütme, bilgiyi düzenleme, genellemelere varma, kanıtlama ve en önemlisi problem çözme_becerisidir (Toluk, 2003).

\section{Matematik ve Teknoloji}

Günümüzde öğrencilerin öğrenme kanalları etkileyen önemli bir husus teknolojideki kökten değişikliklerdir. Teknolojideki değişimler; matematik derslerinin yeniden yapılandırılması, ders içeriklerinin güncellenmesi ve matematik öğrenimi için yenilikçi yolları beraberinde getirmiştir. Matematik alanında yapılan birçok çalışmada teknolojinin matematik eğitiminde büyük ve önemli rol oynayacağı belirtilmektedir (NCTM, 2000).

Bilgisayarların eğitimde kullanımını sadece teknolojideki yeniliklerin ortaya çıkışıyla açıklamak yetersiz bir açıklama olacaktır. Şöyle ki; eğitim talebinin aşırı derecede artması, içeriğin karmaşık olması, öğretmen yetersizliği, bireysel yetenek ve farklılıkların önem kazanması gibi nedenler; matematik eğitiminde yenilikçi yollar kullanma talebini doğurmaktadır. Bilgisayar kullanımı matematik eğitiminde uygulama, öğretme ve öğrenme süreçlerinde etkinlik, devamlılık ve bütünlük sağlamayı hedef alır (Çuhacı, 1985, s. 28).

Bilgisayar Destekli Öğretim ile öğrencinin hayal etme gücü artmaktadır. Matematikte hayal etme gücünün artması sezgi yolunun dolayısıyla yaratma ve keşfetme yollarının açılması demektir. $\mathrm{Bu}$ yollar açıldığında öğrenci analiz yapabilecek, varsayımda bulunabilecek ve genelleme yapabilecektir. $\mathrm{Bu}$ ise doğrudan öğrencinin problem çözme 
becerilerini geliştirecektir (Baki, 2001). Bu tasarım ile birlikte bugüne kadar tümdengelimci bir yapı içerisinde çalışılan ve yapılan birçok araştırma ile öğrencilerin başarısız olduğu tespit edilen geometri eğitimine tümevarımcı yeni bir bakış açısı getirilebilir.

Geometri derslerinde yalnızca yazı tahtası-tebeşir ve kâğıt -kalem -cetvel kullanılarak öğretim yapılmakta ve sınırlı sayıdaki çizimlerle öğrencilerden uzamsal görselleştirme düşüncelerinin geliştirilmesi beklenmektedir. $\mathrm{Bu}$ durumun değiştirilmesi gerektiği açıktır. Dolayısıyla öğrencilerin geometrik şekilleri ve özelliklerini daha iyi görebilme yetisini geliştirmek için daha çok ortam sağlanması gerekir. $\mathrm{Bu}$ doğrultuda Geometer’s Sketchpad(GSP) ile oluşturulan dinamik geometri ortamları, öğrencilerin geometrik şekilleri hareket ettirerek, biçimlerini değiştirerek ve ölçümler yaparak şekillerin özelliklerini keşfedebilecekleri ve ilişkilendirebilecekleri öğrenci merkezli ortamlar yaratmaktadır (Vatansever, 2007) .

Öğrenciler dinamik geometri yazılımlarıyla deneyerek, keşfederek ve en önemlisi kendileri yaparak, yaşayarak öğrenmektedirler.

\section{Matematik ve Sanat}

Matematik ve sanat; malzemeleri, teknikleri, yöntemleri ve doğal olarak ürünleri farklı iki alandır. İlk bakışta hemen göze çarpan ve rahatsızlık veren bu ayrılık, matematik ve sanatın ortaklıklarının varlığına engel değildir. Matematik de sanat da, diğer bilimler gibi, insanın içinde doğduğu ortamı ve bu ortam içinde kendine ne olup bitmekte olduğunu anlama çabası sonucu doğmuştur. Zaman zaman doğaya aykırı görünseler de iki alan da doğanın soyutlaması, yorumu hatta yeniden sunumudur. Sayılar, denklemler bu halleriyle doğada yokturlar ama resimler ve heykeller gibi doğayı betimler ve düşüncemize yeniden sunarlar (İpek ve diğerleri, 2010).

Bunun yanı sıra; Milli Eğitim Bakanlığı'nın matematik dersi öğretim programı ve kılavuzunda matematik eğitiminin genel amaçları arasında yer alan 'Matematik ve sanat ilişkisini kurabilecek, estetik duygular geliştirebilecektir' (Milli Eğitim Bakanlığı, 2011) maddesine dayanarak da Anadolu süslemelerindeki geometri, derslerde incelenebilir.

\section{İslam’ in Geometrik Süslemeleri}

İslam'ın geometrik süslemeleri olarak bilinen İslam sanatının pek çok örneği Selçuklu ve Osmanlı Devletlerinin yaşamış olduğu coğrafyalarda gözlemlenebilmektedir. Bu süslemelerin nasıl oluşturulduğuna ilişkin tartışmalar ise devam etmektedir. Bazı yazarlar bu 
süslemelerin tasarımcılarının üst düzey(sofistike) geometri kullandığını savunmaktadır. Bir diğer grup ise bu süslemelerin oluşturucularının çalışmalarında matematik kullanıldığına dair bir delil bulunmadığını savunan yazarlardır. Bununla birlikte; herkes, İslam süslemelerinin matematik bakış açısından, oldukça ilginç olduğunu ve matematiğin, özellikle geometrinin bu süslemeleri incelemede faydalı olabileceğini kabul etmektedir(Majewski, 2011).

İslam dininde insan ve hayvan tasvirinin (resim ve heykellerin) geçmişte yasaklanmış olması, ayrıca hendese(geometri) bilimine verilen önem, süsleme sanatında geometrik şekillerin ağırlıklı olarak kullanılmasına yol açmıştır. İslam sanatında saray, cami, mescit, medrese, han, kervansaray, türbe ve mezar taşı yüzeylerinin süslenmesinde, yazı ve bitkisel şekillerle birlikte geometrik şekiller de sıkça kullanılmaktadır. Orta Asya'dan Türkler tarafindan geometrik şekillerle, İslam kültürünün birleşimi sonucu ortaya çıkan Selçuklu yapılarındaki geometrik süslemeler, zamanına göre çok ileri ve etkileyici güzelliktedir. Selçuklu süsleme sanatında periyodik kaplanabilen eşkenar üçgeni kare ve düzgün altıgen şeklindeki karoların, kenarlarıyla birbirlerine uyacak şekilde oynayarak ya da aynı düzgün geometrik şekli birleştirerek oluşturulmuş tek karoyla, pek çok güzel periyodik kaplama yapılmıştır (Arık ve Sancak, 2007).

Selçuklu döneminde tek karo kullanılarak, karonun iki dik doğrultuda sırayla bir kendisi, bir de yansıması (ya da 180 derece dönmüş hali) olacak şekilde ilerlediği kaplamalar da yapılmıştır. İki veya daha fazla türde karo kullanmak çok değişik kaplamalar yapabilme seçeneği sunduğundan, bu tür süslemeler Selçuklu ve İslam sanatında da geometrik şekillerle yapılmış kaplamaların büyük çoğunluğunu oluşturur (Arık ve Sancak, 2007).

Osmanlı İmparatorluğu'nda, Selçuklu' dan miras olarak alıp geliştirdiği, geometrik şekillerden oluşan süsleme tekniğinin önemli bir yeri vardır. Bu geometrik şekillerle süsleme tekniği Osmanlı İmparatorluğu'nun en önemli mimari eserlerinden olan Süleymaniye Cami, Sultanahmet Cami, Topkapı Sarayı'ndaki Bağdat Köşkü, Revan Köşkü gibi özellikle 16. Ve 17. yüzyıllarda yapılmış olan mimari eserlerin genellikle çift kapı kanatlarından karşımıza çıkmaktadır (Arık ve Sancak, 2007).

\section{Çalışmanın Amacı}

$\mathrm{Bu}$ çalışmanın amac1, “Anadolu Süslemeleri” temasını seçen öğretmen adayları arasından farklı süslemeleri kullananların bu süslemelere ulaşırken izledikleri yollar ve kullandıkları geometrideki bazı önemli kavramları göstermektir. Ayrıca öğretmen adaylarından bitirme projelerinin yanında dersin işlenişi, GSP programı ve kendi yaptıkları 
ödevleri ile ilgili görüşleri alınarak, dersin uygulamalı olarak işlenmesinin yararlılığı, GSP' nin geometri öğretiminde faydalılığı ve yaratıcılığa katkısı olup olmadığını incelemektir.

\section{Yöntem}

\section{Örneklem}

Bu çalışmada, 2011-2012 öğretim yılında Ege Üniversitesi Eğitim Fakültesi'nde öğrenim gören, “Özel Öğretim Yöntemleri” dersini alan toplam 125 Matematik Formasyon ve Bilişim Teknolojileri öğretmen adayının bitirme projesi incelenmiştir. Öğretmen adayları bu ders kapsamında GSP programını da öğrenmişlerdir. Öğretmen adayları bitirme projelerinin temalarını seçme konusunda özgür bırakılmışlardır. Öğretmen adayları seçtikleri süslemeleri GSP yardımıyla oluşturmuşlardır. Toplam 42 öğretmen adayı bitirme projesi teması olarak “Anadolu Süslemeleri” ni seçmiştir.

\section{Çalışmanın Tanıtılıası}

Öğretmen adayları yapacakları projenin temasına karar verirken serbest bırakıldıkları için gerçek yaşantıdan esinlenmişlerdir. Örneğin; internette gördükleri ya da etraflarında bulunan çini motiflerinden, gömleğinin deseninden, annelerinin el işi dergilerinden hatta derse gelirken ellerinde bulunan bir torbanın desenine kadar pek çok farklı ortamdan yararlanmayı seçmişlerdir. Oluşturdukları desenleri kutu kaplama, resim çerçevesi, bardak ve tabak baskısı şeklinde değerlendirmişlerdir (Şekil1).

Öğretmen adaylarının çalışmalarından iki farklı örnek seçilmiş ve bu örnekler GSP ortamında oluşturulurken izlenen yollar detaylı olarak aşağıda gösterilmiştir.

\section{Örnek 1}

Bu örnekte, öğretmen adayı otantik bir Türk halısında gördüğü deseni GSP ortamında çalışmıştır. Aşağıdaki şekilde öğrencinin kendi anlatımıyla hazırladığı “Örgü Halı Deseni” isimli ödevi bulunmaktadır (Şekil 2).

\section{Örnek 2}

$\mathrm{Bu}$ örnekte öğretmen adayı, Arık ve Sancak 'ın Pentapleks Kaplamalar isimli kitabında gördüğü deseni GSP ortamında çalışmıştır. Aşağıdaki şekilde öğrencinin kendi anlatımıyla hazırladığı “As Enflasyonlu Kaplama” isimli ödevi bulunmaktadır (Şekil 3). 
Öğretmen adaylarından bitirme projelerinin yanında dersin işlenişi, GSP programı ve kendi yaptıkları ödevleri ile ilgili görüşlerini yazmaları da istenmiştir.

\section{Bulgular}

Aşağıda bazı örnekleri verilen öğretmen adayları görüşleri incelendiğinde; tüm öğretmen adaylarının dersin uygulamalı olarak işlenmesinin yararlı, GSP 'nin geometri öğretiminde oldukça faydalı olduğunu ve yaratıcılıklarına olumlu etki sağladığını ifade ettikleri gözlemlenmiştir. Öğretmen adaylarının ödevleri incelendiğinde ise; seçtikleri desen ya da motifi oluştururken geometrik kavramlardan kolayca yararlanabildikleri görülmüştür. İlk başta zor bir geometri problemi olarak görülen hedef desenlerini, GSP programı yardımıyla kolayca oluşturabilmişlerdir. Bu durumun öğretmen adaylarının geometriye karşı olumlu tutum geliştirmelerine katkı sağladığı gözlemlenmiştir. Ayrıca yaptıkları bu çalışmaların günlük hayatlarında karşılaştıkları geometrik nesne ve desenlere yönelik farkındalık yarattı̆̆ı saptanmıştır.

\section{Öğretmen Adayları Görüşlerinden Örnekler}

ÖA1: "Dersin hem uygulamalı olması hem de geometrideki formüllerin ispatının yapılıyor olması dikkat çekiciydi. Geometride ki formüllerin hem ispatı hem de eğlenceli hali diye açıklayabilirim. Ayrıca geometrik şekilleri kullanarak, bu şekilleri farklı farklı konumlandırarak yaratıcılıkla motifler üretmeye olanak buldum. Dersler ilerledikçe günlük hayatta karşıma çıkan motiflerin en küçük parçasının ne olduğunu bulmaya çalıştığımı fark ettim. Aslında günlük hayatta çoğu şeylerin küçük motiften oluştuğunu anladım. Burada bir bakıma tümevarım yöntemini kendi gözlerimle anlamış oldum. Ayrıca karşıma çıkan motiflerin en küçük parçasını bulmaya çalışırken aslında buluş yöntemini kullandığımı fark ettim. Ayrıca arkadaşlarımla da İşbirlikli çalışma firsatı bulmuş olduk.”

ÖA4: “GSP' nin insanın yaratıcı yönlerini ortaya koymasını sağlayan bir araç olduğu kanaatindeyim.”

ÖA9: "Basit çizimlerle karmaşık geometri problemlerini çözümlerini kolayla sunabileceğimiz kolay bir program. Hem yaratıcılığıma hem de düşünce dünyama kazanımlar sağladım.”

ÖA11: "Dersimiz ilerledikçe her gördüğüm nesneye bakıp, bunu GSP ile nasıl modelleyebilirim diye düşünmeye başladım." 
ÖA14: "Yaratıcılığımızı öne çıkaran bu program başta kullanımı ile beni zorladı. Daha sonra özelliklerini kavradıkça pratik bir program olduğunu keşfettim. Bir şeyler üreterek öğrenmenin keyfini yaşadım. Geometri formüllerini bizzat kendim ispatlama fırsatı buldum ve kardeşlerime de öğreterek geometrinin zor bir ders olmadığını onlarla da paylaştım.” ÖA17: "Kendimi bu programda geliştireceğim. Çünkü okulda öğrencilerime ders anlatırken; dikkat çekmek, daha verimli ders işlemek ve daha iyi bilgi vermek için bu programı daha da iyi bilmem gerekiyor.”

ÖA23: “Araştırma, keşfetme ve becerilerimizi geliştirme açısından GSP'nin yararlı bir uygulama olduğunu düşünüyorum. Ayrıca geometrik teoremler, ispatlar ve örnekler içinde uygun bir program. Kullanım kolaylığına rağmen pek çok zor projenin oluşturulabileceği, hoş vakit geçirilebilen bir program.”

ÖA24: "Yaratıcılığımı kullanmak, bir çizgiden tahmin edemeyeceğim güzellikte şeyler yaptığımı görmek programı daha çok sevmemi sağladı. Üstelik bunları yaparken geometri kullanmak kendime olan güvenimi arttırdı. Bu ders sonunda boş zamanlarımı değerlendirmek için yeni bir uğraş daha bulmuş oldum."

ÖA36: “GSP programının adını ilk defa duyduğumda bana sadece geometrik şekillerin açılarını, kenar uzunluklarını hesaplayan, gösteren bir program gibi gelmişti. Ancak daha sonra programda yapılabileceklerin farkına vardığımda fikrim değişti, GSP sadece bir ders değil, geometri ile iç içe bir hobi gibi eğlenceli bir hal aldı.”

ÖA43: "Bu proje; estetik bakış açısını, odak noktayı, dikkat ve motivasyonu ön plana çıkardı. Daha önceki tecrübelerim sayesinde zorlanmadan bu projeyi ürettim. Proje sonunda estetik bir parça üretmem bu programı kullanma isteğimi arttırdı. Boş zamanlarda yeni şeyler üretmek amacıyla bu programa sanırım zaman ayıracağım.”

\section{Sonuç ve Öneriler}

Öğretmen adaylarının bitirme ödevlerini hazırlarken; “Anadolu Süslemeleri” nde kullanılan düzgün çokgenlerin oluşumu, bir çember içine çizilen ve etrafinda dolanan şekillerin oluşturulması, açıların ve doğruların verilen bir sayı kadar eşit parçaya bölünmesi, şekillerin yansıma, öteleme ve dönmeleri, simetri grupları, süslemelerin renklendirilmesi ve daha pek çoğunu kullanabildikleri görülmüştür.

Öğretmen adaylarının ödevlerine yazmaları istenen görüşleri incelendiğinde; tüm öğrencilerin dersin uygulamalı olarak işlenmesinin yararlı, GSP'nin geometri öğretiminde 
Ege Eğitim Dergisi 2014 (15) 2: 521-537

Anadolu Süslemelerindeki Geometri

oldukça faydalı olacağı ve yaratıcılıklarına olumlu etki sağladığını ifade ettikleri gözlemlenmiştir.

Bu nedenle, İslam'ın geometrik süslemeleri matematik ve sanatın bir birleşimi olarak matematik öğretiminde kullanılabilir. 


\section{Kaynakça}

Altun, M. (2005). Matematik öğretimi, İstanbul: Alfa Basım Yayım dağıtım.

Arık, M. ve Sancak, M. (2007). Pentapleks kaplamalar. Ankara: Tübitak.

Baki, A. (2001). Bilişim Teknolojisi Işı̆ğ Altında Matematik Eğitiminin Değerlendirilmesi , Milli Ë̆itim Dergisi, Sayı 149.

Çuhac1, M. N. (1985). Bilgisayarlarla eğitim. Eğitim ve Bilim Dergisi, 54, 28-31.

Bintaş J.-Özmüş P.-Giziroğlu G.-Kıyak F., Matematik Öğretmen Adaylarının Dinamik Geometri Yazılımı ile Matematik ve Sanata Bakışları: "Piet Mondrian Örneği”, Ijonte, 2010.

Milli Eğitim Bakanlığı (2006). İlköğretim matematik dersi 6-8. sinıflar öğretim programı ve kılavuzu. Ankara: Yazar.

Majewski, M. (2011). Islamic Arts in Mathematics Classroom, Bolu Abant İzzet Baysal Üniversitesi Kongre Merkezi, 02.05.2011.

National Council of Teachers of Mathematics: Commision on Standarts for School Mathematics (1989). Curriculum on evaluation standarts for school mathematics. Reston, VA: The Council.

NCTM (2000). The principles and standards for school mathematics. Reston, VA: Author.

Toluk, Z. (2003). Üçüncü Uluslararası Matematik ve Fen Araştırması (TIMSS): Matematik Nedir?. http://ilkogretim-online.org.tr/vol2say1/v02s01e.htm adresinden elde edildi. (23 Ocak 2006).

Vatansever, S. (2007). İlkögretim Yedinci Sınıf Geometri Konularını Dinamik Geometri Yazılımı Geometer's Sketchpad ile Öğrenmenin Başarlya, Kalıcılı̆̆a Etkisi ve Öğrenci Görüşleri. (Yayımlanmamış yüksek lisans tezi). Dokuz Eylül Üniversitesi, İzmir. 
Ege Eğitim Dergisi 2014 (15) 2: 521-537

Anadolu Süslemelerindeki Geometri

\section{Ekler}

Şekil 1:

Öğrencilerin çalışmalarından örnekler
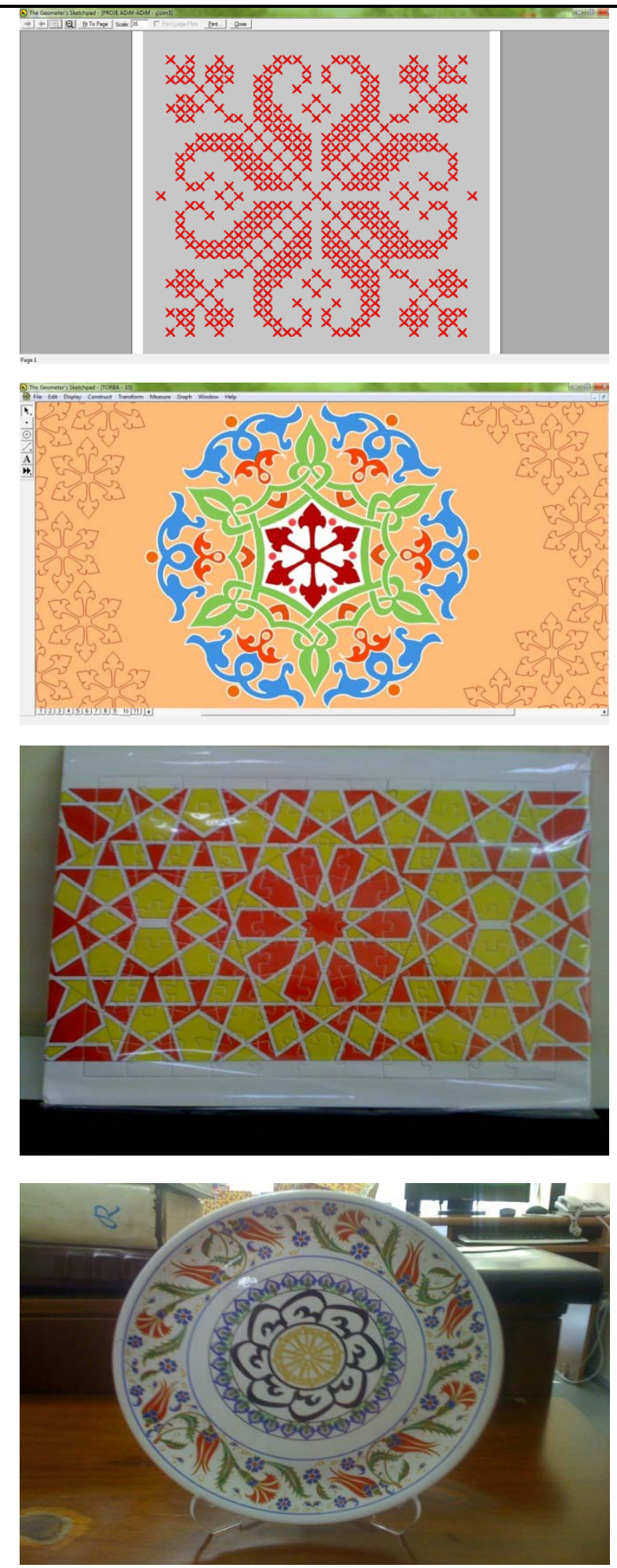
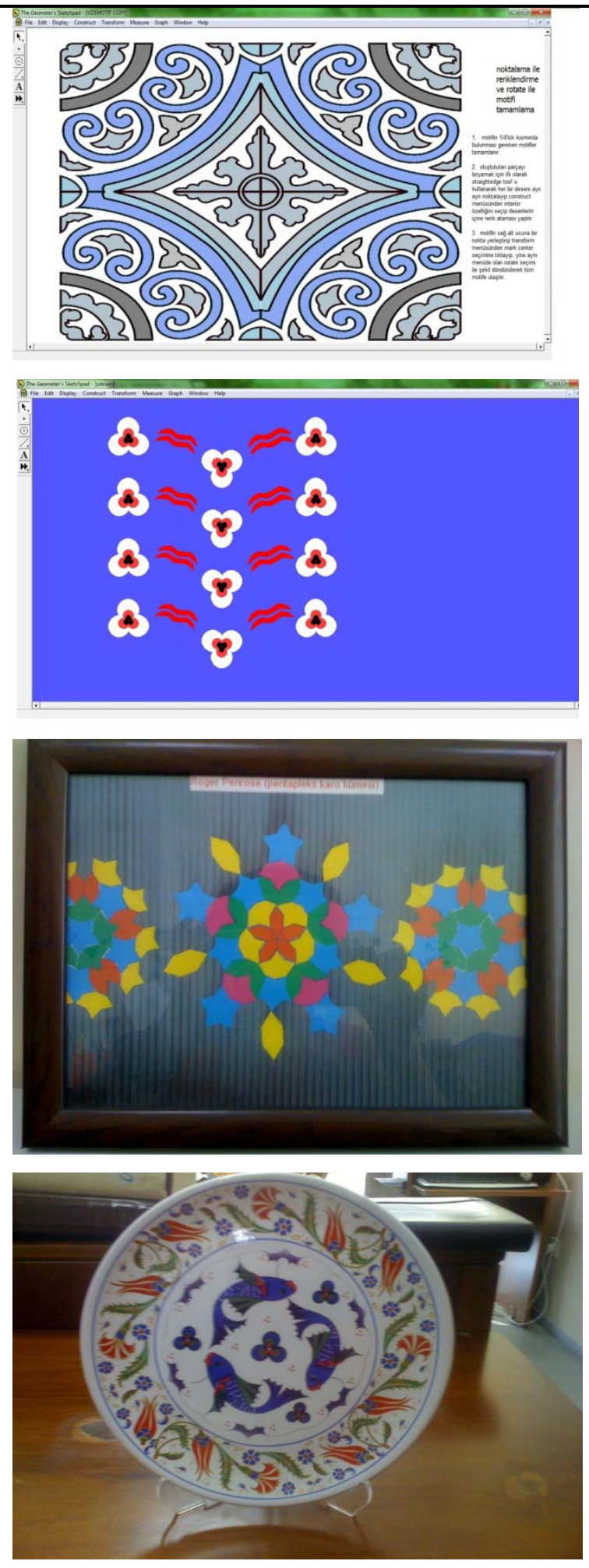


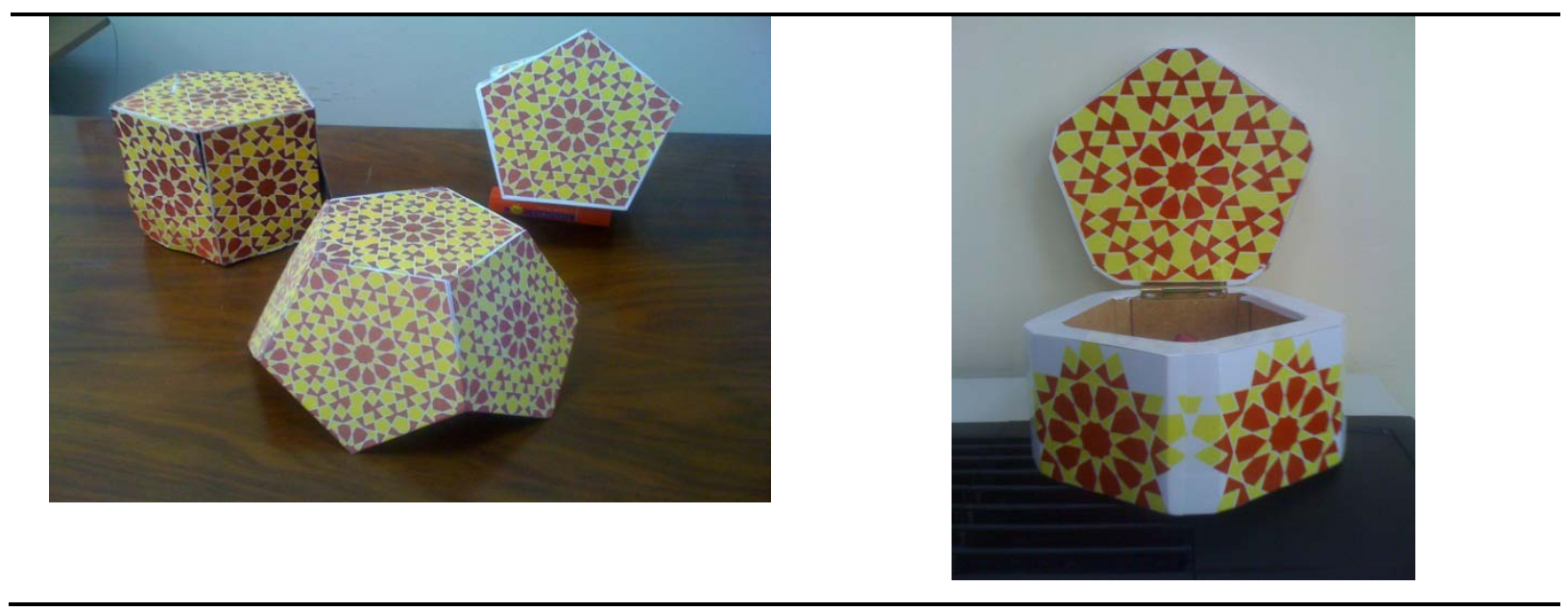

Şekil 2:

“Örgü Halı Deseni” nin anlatımı

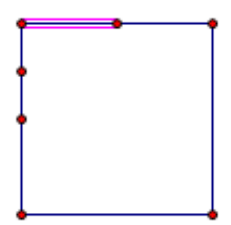

1. Öncelikle boş bir GSP sayfası açıp kare çiziyoruz.
2. Daha sonra karenin her bir kenarlarına mid point koyuyoruz. Sonra her kenardan mid pointe bir segment daha çizip tekrar mid point yapıp her kenarı 4 eş parçaya bölüyoruz.

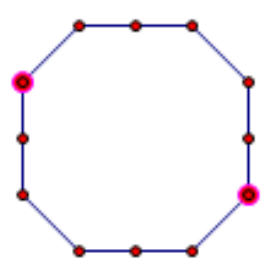

4. Her bir kenara segmentleri çizdikten sonra sekizgeni

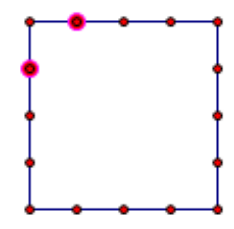

3. Sonra ikinci çizdiğimiz midpointler arasında kenardan kenara segment atıoruz ve sekizgen oluşturuyoruz.

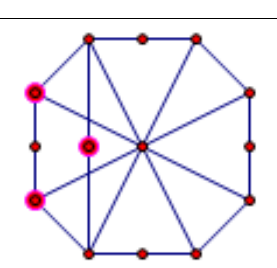

5. İki kenara içe doğru koyup "arc through 3 points"
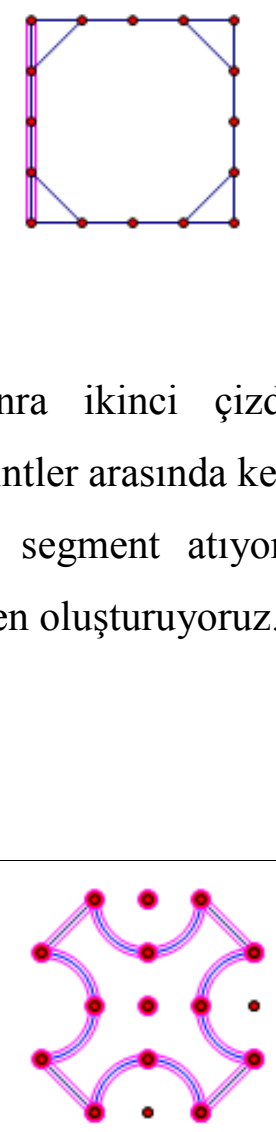

6. Dairesel çizgilerden sonra diğer segmentleri silip 


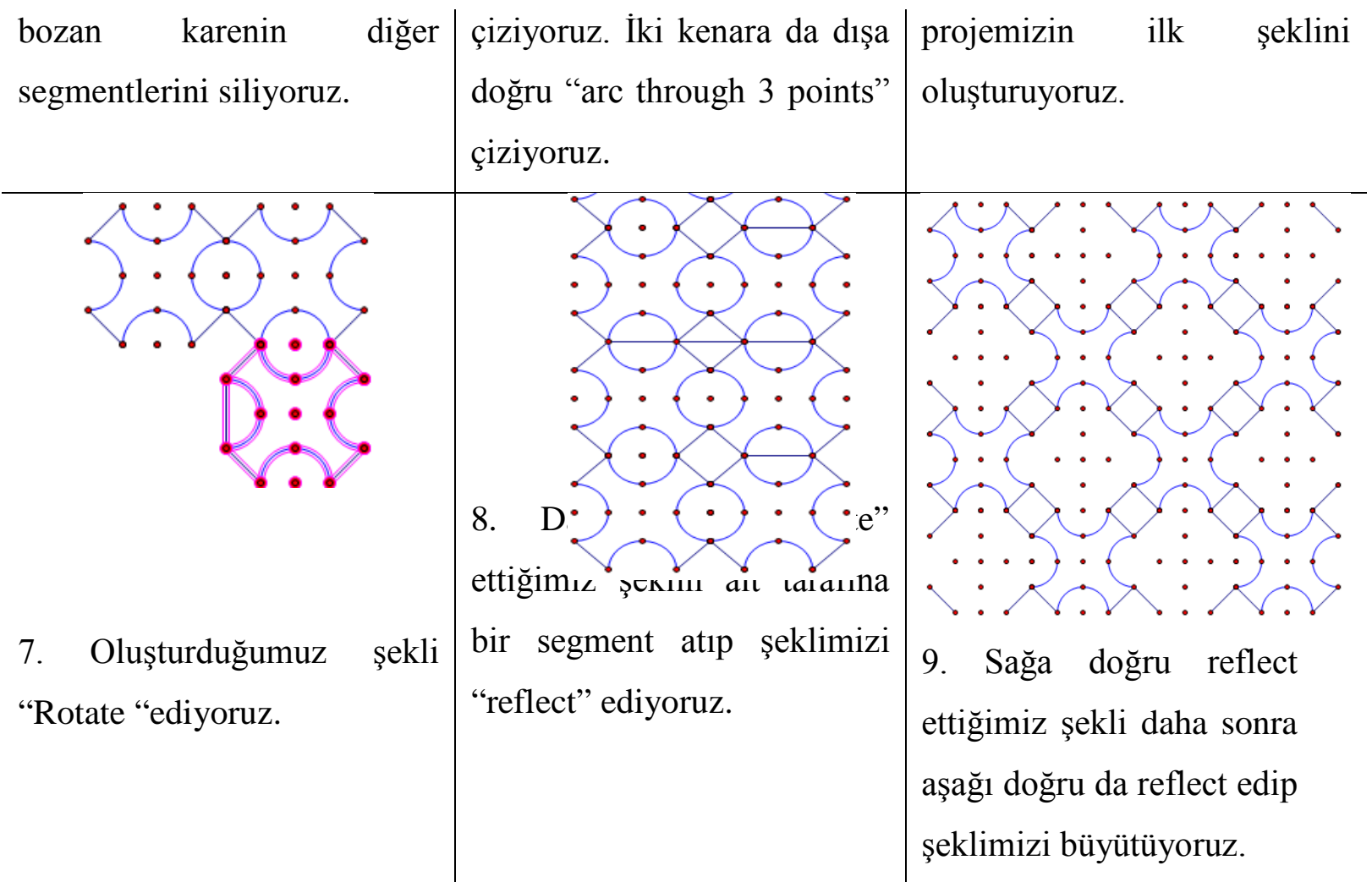

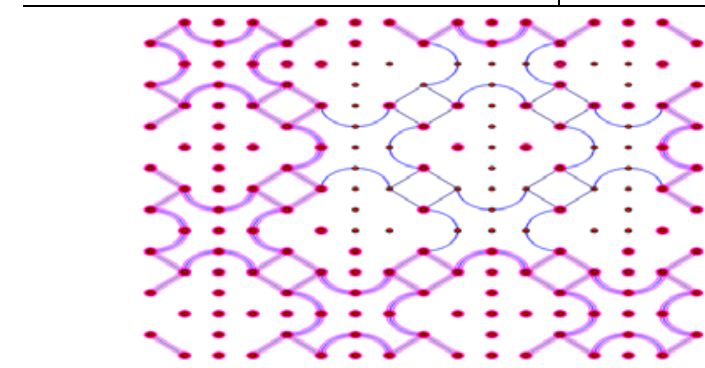

10. Şeklin tamamını seçip motifimizin ana hatlarını oluşturacak yeri seçimden çıkarıp diğerlerini hide ediyoruz.

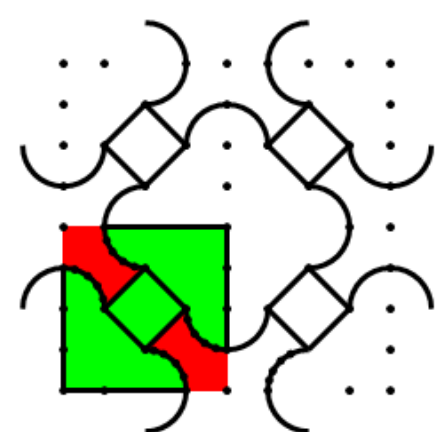

12. Dairesel çizgilere sik noktalar koyup hepsini seçip "Polygon interior”dan
11. Ve motifimizin ana şekli ortaya çıkıyor.
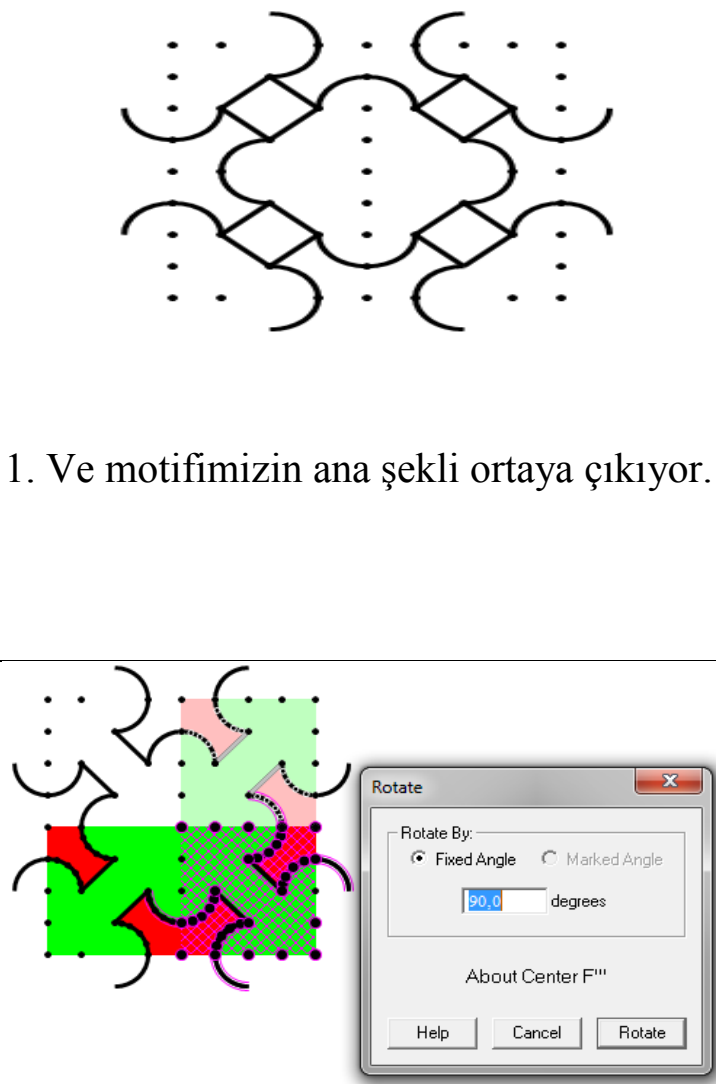

13. Daha sonra bu şekli dört kez rotate 


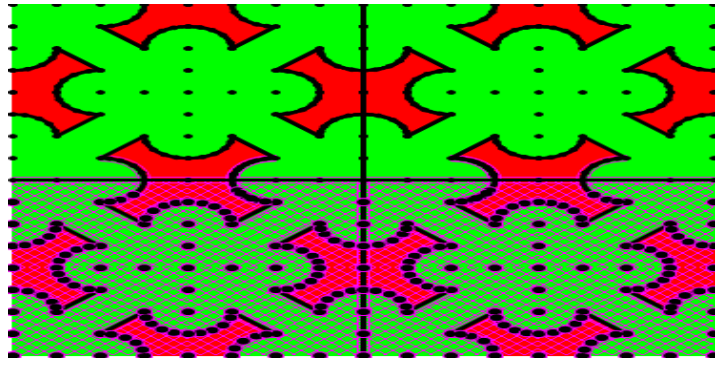

14. 4 kez rotate ettiğimiz şeklin tamamını seçip tekrar rotate ediyoruz ve şeklimizi oluşturuyoruz.

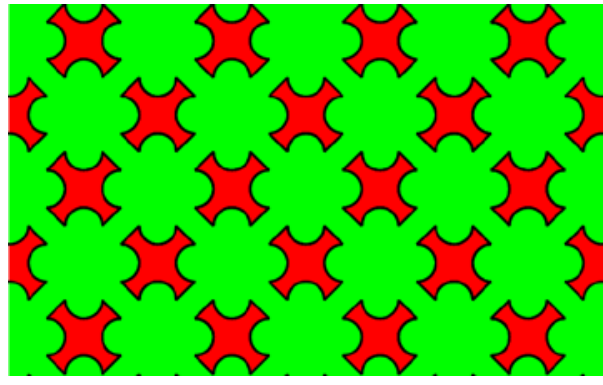

15. Noktaları sildikten sonra işte Örgü Halı Modelimiz hazır

\section{Sekil 3:}

"As Enflasyonlu Kaplama" isimli desenin anlatımı

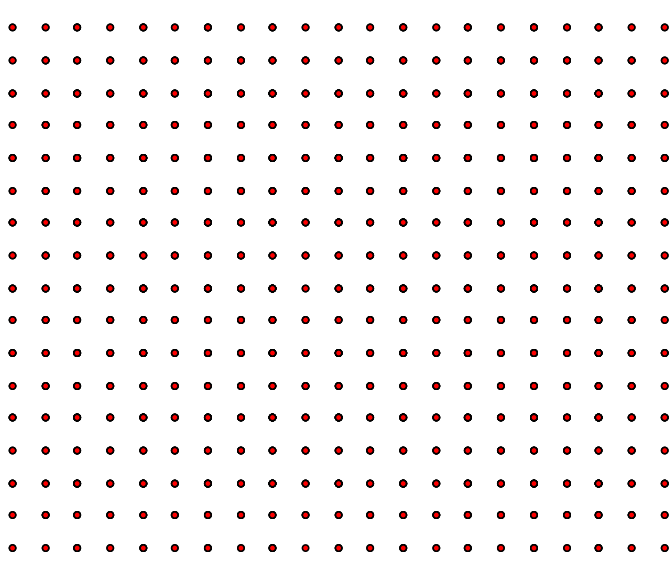

1. Çizimimizi daha düzgün şekillerde yapmak için karesel noktalı kâğıt oluşturuyoruz. Bunun için Shift+segment aracıyla bir doğru çiziyoruz. daha sonra doğrunun sağ köesindeki noktayı çift tıklatıp rotate diyoruz 90 derece açı ile döndürüyoruz. Kare haline gelene kadar devam ediyoruz. Ardından karenin sağ köşesindeki segmente çift tıklayıp Refleck seçeneğini aktifleştiriyor ve Transform'dan Reflecte tıklıyoruz. İstediğimiz büyüklüğe

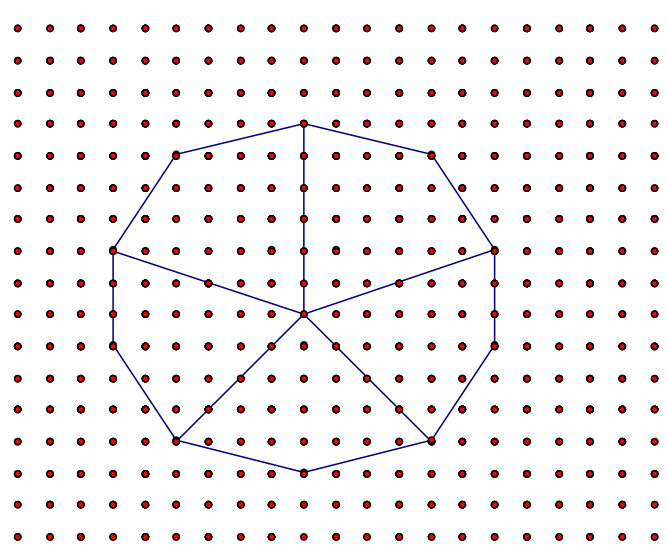

2. Önce temel şeklimiz olan sekizgeni çiziyoruz. Şekildeki gibi noktaları birleştirerek segment oluşturuyoruz. Düzgün olması için noktalı kâğıda yapmamız önemli. Sonra şeklimizi renklendiriyoruz.

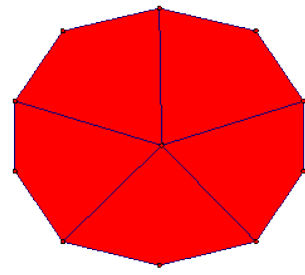


Ege Eğitim Dergisi 2014 (15) 2: 521-537

Anadolu Süslemelerindeki Geometri

gelene kadar bu işleme devam ediyoruz.

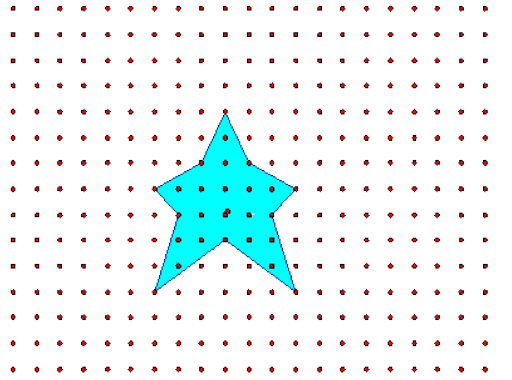

3. Şimdi temel desenlerimizden biri olan sekizgen içinde yer alan yıldız desenimizi çiziyoruz. Burada yapacağımız işlem şekle göre noktalardan yola çıkarak çizmek. Yani yapacağımız şekle göre iki noktayı seçerek Ctrl+L diyoruz ve segmentimizi oluşturarak işlemi şekildeki gibi olacak şekle gelene kadar çizimimize devam ediyoruz.

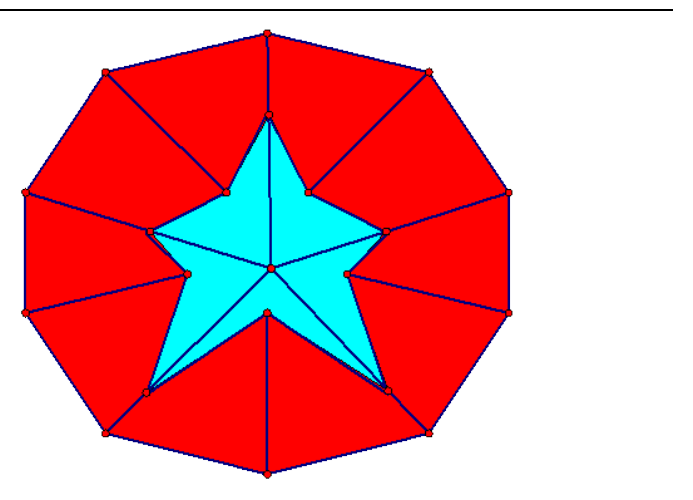

4. Oluşturduğumuz yıldızı beşgenin içine yerleştiriyoruz. 


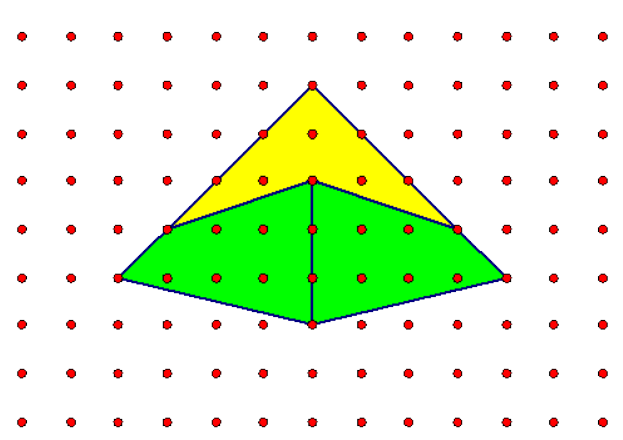

5. Temel çizimlerimizi yapmaya devam ediyoruz. $\mathrm{Bu}$ çizimimizde aynı şekilde segment oluşturularak yapılıyor $\mathrm{Ctrl}+\mathrm{L}$ ile.Renklendirme işlemi ise renk vereceğimiz şeklin noktaları seçilerek ardından $\mathrm{Ctrl}+\mathrm{P}$ tuşlarıyla yapılmıştır.

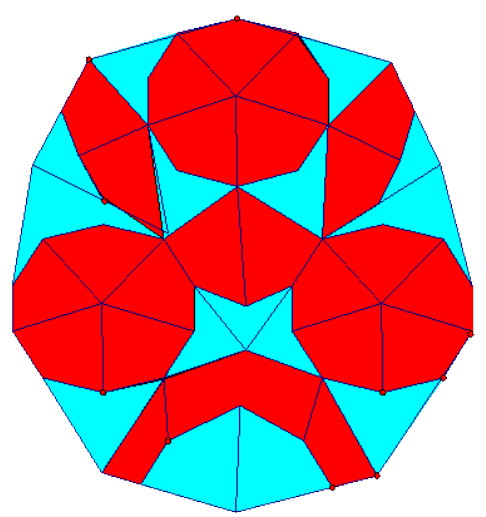

6. İlk önce çizimimizin orta kısmını yapıyoruz bu şekli ilk sayfalarda çizdiğimiz temel desenlerimizden bir araya getiriyoruz. Elimizde bulunan şekle göre desenler arasında kalan şekillerimizi de tamamlıyoruz. Bunu segmentleri bir araya getirerek oluşturuyoruz.

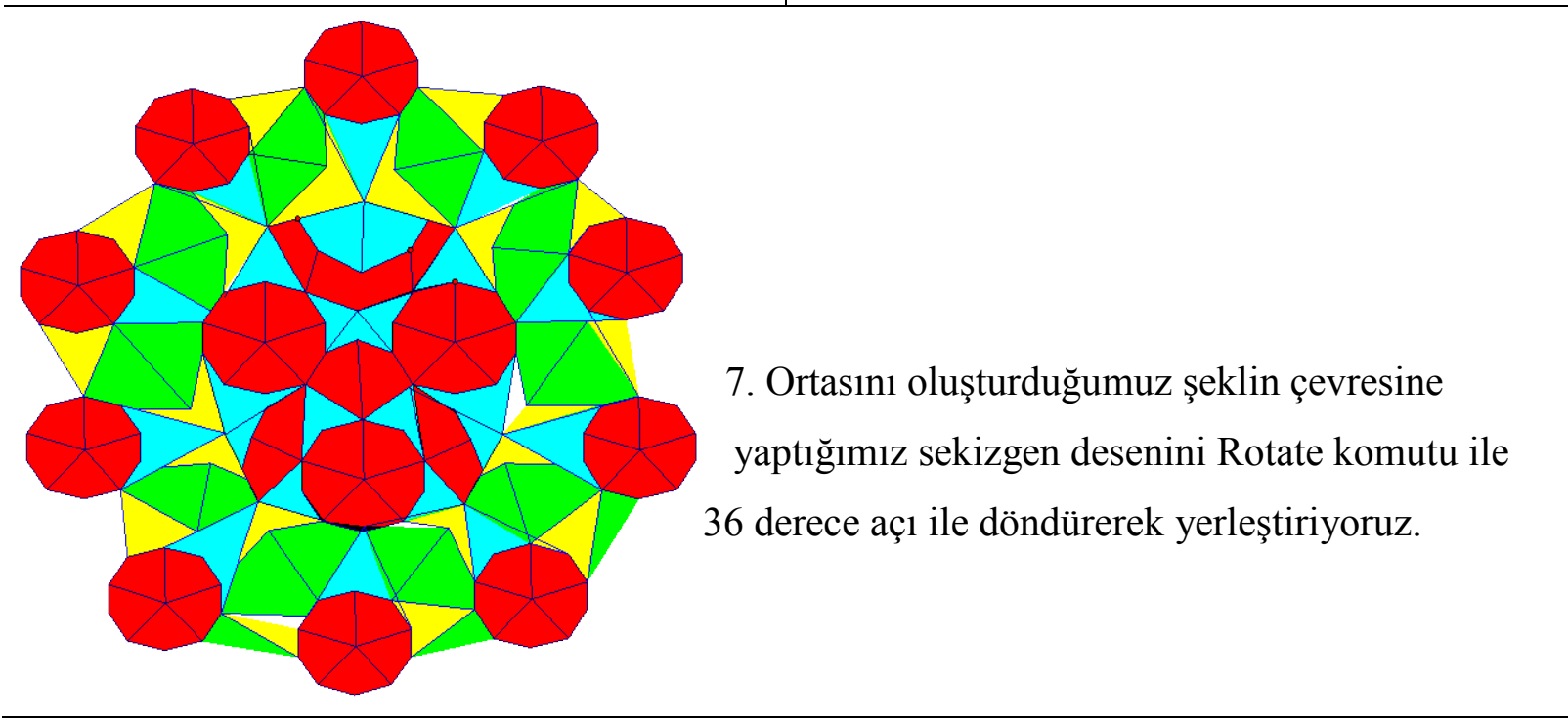




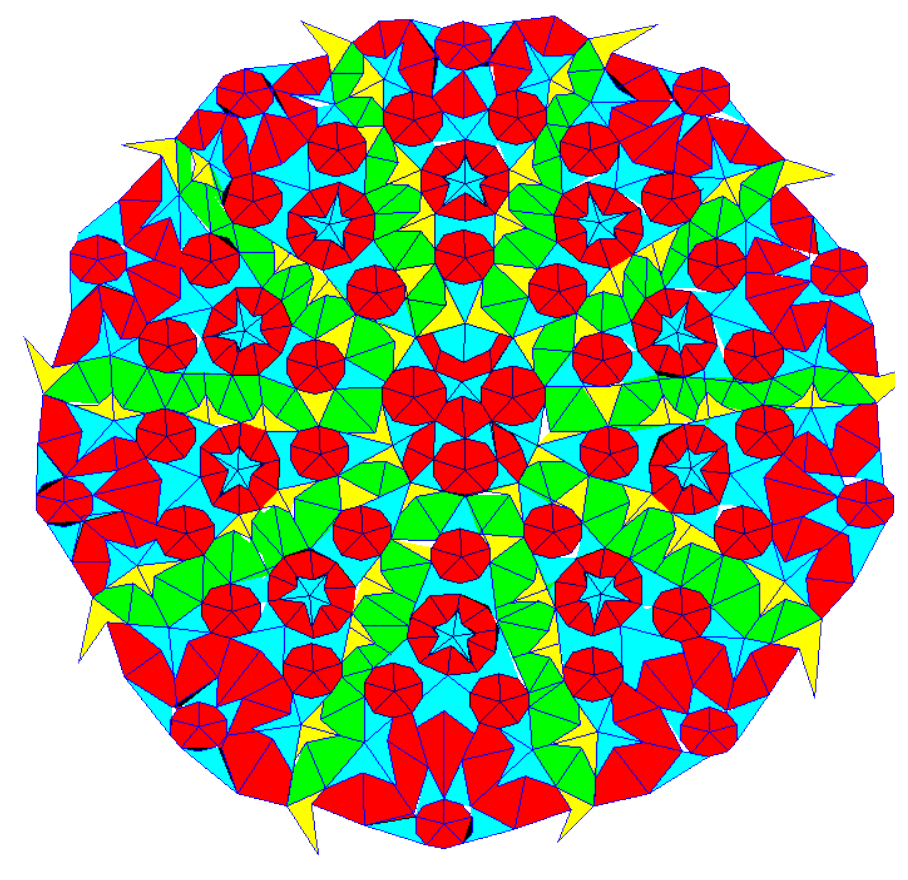

8. Daha sonra ise ortasinda y1ldız olan sekinzgen desenimizi de aynı şekilde rotate ile 36 derece açı ile önceki işlemin üzerinden uyguluyoruz.

Ardından yine sade olan sekizgeni önceki şeklimizin üzerinden 18 derece açı ile Rotate ediyoruz.

Son olarak aynı deseni 36 derece açı ile son kısma Rotate ediyoruz ve temel olarak desenimiz tamamlandi.

Geri kalan işlemleri ise elimizdeki desene göre segment oluşturarak yapıyoruz. Sarı yeşil yaptığımız önceki deseni yerleştiriyoruz. Segmentleri $\mathrm{C}$ trl $+\mathrm{L}$ ve rengide renk vereceğimiz şeklin noktalarını seçili halde bulundurarak $\mathrm{Ctrl}+\mathrm{P}$ yaparak veriyoruz ve şeklimiz son haline geliyor. 